М.О.Петренко,

аспірант Київського університету туризму, економіки і права

\title{
ІДЕЯ СУВЕРЕННОСТІ ТА ГІДНОСТІ ЛЮДИНИ У ФІЛОСОФСЬКІЙ АНТРОПОЛОГІЇ БЛЕЗА ПАСКАЛЯ
}

Суверенності та гідності людини належить одне з чільних місць серед інших моральних чеснот та цінностей: саме на них люди мусять зважати у своїх взаєминах, адже це - не пересічні моральні цінності, які існують поруч з іншими цінностями, такими як свобода, справедливість чи право. Осягнення історико-філософських засад розуміння суверенності людини та ії гідності є, безперечно, актуальним і сьогодні, в часи глибокої соціальної та світоглядної кризи. Саме в означеному контексті ми й звертаємося до основних принципів тлумачення ідеї суверенності людини та ії гідності у філософській антропології видатного французького філософа Блеза Паскаля, який, разом зі своїм знаменитим сучасником Ф.Беконом, безумовно, стояв у витоків формування не лише сучасної філософської, але й політичної антропології.

Незважаючи на критичне ставлення до деяких міркувань Р.Декарта, Б. Паскаль також поділяв його відому тезу про те, що ми можемо сумніватись в усьому, але безперечним є факт нашого мислення. Б.Паскаль, так само як і Декарт, належить до класиків новочасового мислення, постулюючи людське Я як засаду своїх міркувань. Проте, на відміну від другого, він говорить про недосконалість людини, світоглядно та онтологічно вкорінену трагічність ії буття. Осмислення основних мотивів людського буття, його суверенності та гідності в творчості Блеза Паскаля й $є$ предметом нашої статті. Уважний аналіз роздумів цього мислителя про суверенність та гідність людини дасть нам можливість всебічно розкрити й глибше зрозуміти сутність історичної трансформації проблеми людської гідності, розмаїття іiі сутнісних характеристик у процесі соціально-історичного розвитку.

Філософсько-антропологічні здобутки Б.Паскаля, незважаючи на їх досить помітний вплив на європейську філософську думку, ще не стала предметом всебічного вивчення у вітчизняній філософіiі. Хоча, безперечно, значним внеском у розуміння творчого доробку Паскаля є український переклад О. Хомою та А.Перепадьою 
головної праці філософа, його «Думок». У своїй післямові до перекладу О. Хома, розглядаючи історію визнання Б. Паскаля як публіциста та мораліста, наполягає на необхідності визнання його і як оригінального та глибокого мислителя. Відомий український дослідник та перекладач з французької чи не вперше в Україні веде мову про «філософські засади Паскалевої апологетики», послідовно наголошує на філософсько-герменевтичних принципах паскалевих роздумів, визначаючи їх як «герменевтичну трансформацію картезіанства». На його думку, «автора «Думок» і «Провінціалій» можна назвати одним із засновників новочасної «універсальної герменевтики», як рефлексії про умови розуміння взагалі, заснованого на мовному понятті досвіду» $[1,397]$. Сказане стосується передусім понять «очевидність» та «самоочевидність», які є показниками істинності знань, проте у його філософській антропології набувають подальшого розвитку. У мисленні, думці - і це одна з головних тез Паскаля - втілено нашу гідність. Проте, як буде зазначено далі, у безпосередньому нашому зверненні до тексту «Думок» Паскаль іде далі, за межі власне новочасної теорії пізнання. Він вважає, що «людське розуміння залежить від принципів серця, тому воно вказує передусім на специфіку принципів, які в це серце вкладені; воно радше симптом наших внутрішніх пороків і чеснот, ніж осягнення чогось зовнішнього. Люди розуміють те, що в них вже міститься, i тому методично-раціональне доведення у більшості випадків $\epsilon$ безкорисливим» $[1,399]$.

Варто також звернути увагу й на оцінювання філософії Паскаля відомим сучасним інтелектуалом С.Аверинцевим. Саме він у своїй, виданій в Україні праці «Софія-Логос. Словник» докладно окреслює місце творчості Блеза Паскаля в історії філософії, яке «визначається тим, що це перший мислитель, який, осмислюючи досвід механістичного раціоналізму XVII століття, з усією гостротою поставив питання про межі «науковості», виокремлюючи при цьому відмінні від «доказів розуму» «докази серця» і тим самим вгадуючи ірраціоналістичну тенденцію в філософії (Якобі, романтизм та ін., аж до представників екзистенціалізму). Паскаль відштовхується від образу людини, який сприймається динамічно («стан людини - мінливість, нудьга, неспокій»), не втомлюється говорити про трагічність і тендітність людини і одночасно - про іiі гідність, що полягає в іiі мисленні» [2, 343]. Окреслені С.Аверинцевим ще майже не досліджені у вітчизняній літературі глибинно-трагічні мотиви в 
осмисленні Паскалем людського буття, «величі» та «нікчемності» людини здавна привертають увагу західних філософів. Йдеться не лише про розгляд їх у творах С.К'єркегора, А.Камю, Ж.-П.Сартра, але й про новітні німецькомовні філософсько-антропологічні дослідження, де також можна помітити пильну увагу до виокремлених нами далі мотивів (передусім у його посмертно виданих «Думках») Паскалевого філософування. П.Тідеман, порівнюючи в розділі «Автономне поняття людської гідності» своєї монографії з проблем філософського тлумачення проблеми людської гідності роздуми Піко делла Мірандоли та Б.Паскаля, наголошує на особливості філософського дискурсу Паскаля, яка полягає в постулюванні «рефлексивної самосвідомості як засади людської гідності» [3, 166]. Інший німецький дослідник, Ф.Валлау, вважає, що дослідження європейської філософії людської гідності, яке має прямувати від стоїків через епоху Відродження до епохи Просвітництва, не можливе без звернення до творів Б.Паскаля $[4,25]$. Важливим внеском в осмислення ролі та місця творчості Б. Паскаля в сучасному світі $\epsilon$ також праця відомої російської дослідниці Г.Стрєльцової «Паскаль і європейська культура» [5], де окреслено основні ідеї філософії людини Паскаля, а також уточнено алгоритми та ступінь його впливу на сучасну філософію екзистенціалізму. У розділі «Паскаль і екзистенціалізм» Стрєльцова намагається уточнити дещо прямолінійне твердження П.Тілліха про те, що екзистенціалізм розпочинає відлік свого існування від Паскаля. Варто, на їі думку, говорити швидше про «екзистенціальні мотиви» в роздумах Паскаля про сенс та гідність людського буття.

Як свідчить інтелектуальний дискурс Паскаля, саме людина була осердям роздумів цього філософа; адже самосвідомість, самопізнання, на його переконання, якщо не допоможе людині віднайти істину, то напевне допоможе прожити гідне життя. Це також чи не єдиний шлях до подолання людиною іiі істотних недоліків та вдосконалення власної недосконалої природи. Філософській антропології Паскаля притаманне, з одного боку, розчарування в людині, яка часто не зважає на трагізм життя і $є$ цілком вдоволеною своїм існуванням, сповненим розваг та дріб'язкових проблем, з іншого боку - щире замилування і навіть схиляння перед людиною та іiі розумом. Якщо в гносеологічному сенсі велич людини полягає в прагненні здобути істину, то в сенсі моральному йдеться про природне намагання досягнути добра, досконалості та справедливості. Тож творчість 
Паскаль, цілком правомірно, вважається витоком сучасного екзистенціалізму з його роздумами про сенс, автентичність, але й одночасну безглуздість людського існування. Сказане безпосередньо засвідчують праці А.Камю «Міф про Сизіфа» та «Буття і ніщо» Ж.-П.Сартра.

Б.Паскаль постійно наголошував на тому, що людське існування відбувається між двома безоднями - нескінченно великого й нескінченно малого. Він також мовить про той жах, який навіває на нього вічне мовчання цих нескінченних просторів. Непізнавана за своєю суттю людина є насамперед загадкою для самої себе, істотою, яка не може збагнути природу свого духу та тіла, а також способи поєднання цих двох важливих вимірів людського існування. У своїх «Думках» Паскаль розкриває природу людини, іï місце у світі, сенс людського життя. На його думку, новочасна людина перестала відчувати себе мікрокосмосом. Засвоївши аргументи нової науки про нескінченність світу, вона втратила відчуття своєї сумірності з ним.

Б.Паскаль змалював приголомшливу ще й досі картину безмежного космосу і закликав людину усвідомити своє жалюгідне становище в ньому. «Що таке людина в нескінченному світі?»запитує автор «Думок». Для відповіді на це запитання людині варто «дослідити один із найдрібніших відомих їй предметів. Нехай у крихітному тілі якого-небудь кліща вона розглядає ще дрібніші частинки, ноги з суглобами, вени на цих ногах, кров у цих венах, рідину в цій крові, краплі в цій рідині, пару в цих краплях. Можливо, вона подумає, що це вже найменше в природі. Але я покажу ій нову безодню. Вона побачить безмежну кількість світів, кожний із своїм особливим небом, планетами, землею таких само розмірів, як і наш світ; на цій землі вона побачить тварин та тих самих комах і в них знайде те саме, що і в кліщах; зустрічаючи те саме безкінечно, вона має загубитись в цих чудесах, настільки чудесних у своїй мізерності, скільки в інших за їх величчю» $[6,64]$.

Інше питання, яким переймається філософ: «Що таке людина в природі? Ніщо порівнянно з безмежністю, середина між нічим та всім. Упевнившись в неможливості пізнати коли-небудь початок та кінець речей, вона може зупинитись лише на зовнішньому пізнанні середини між тим чи іншим» $[6,65]$. Саме про серединне становище людини в нескінченності Паскаль розмірковує далі: природно поставлена посередині світу людина не може без наслідків 
змінювати рівновагу свого становища. Це й досить переконливо демонструють такі приклади: «Ми не можемо розуміти ні занадто швидкого, ні занадто повільного читання. Розмірковується погано як у досить юному, так і в досить зрілому віці. Якщо розглядати свою працю відразу після іiї завершення, то буваєш занадто прихильний до неї, а через тривалий проміжок часу - бачиш, що став байдужий до неї» $[6,72]$.

Паскаль звертається і до завжди важливого для філософського дискурсу світоглядного обгрунтування сутності людини, знову наголошуючи на тому, що основною екзистенційною проблемою $є$ проблема становища людини у світі, ставлення до нього, самоусвідомлення та самопочуття в ньому. На його думку, «природу людини можна розглядати 3 двох боків: щодо іï суті, і тоді вона $\epsilon$ великою та незрівнянною, або ж так, як дивиться більшість, з точки зору іiі зовнішності, тоді людина може видатись жалюгідною» [6, 74]. Один із важливих розділів його «Думок» має красномовну назву «Суперечності». В ньому йдеться про невпинний вир людської мізерії та величі: «Оскільки мізерію висновують 3 величі, а велич 3 мізерії, одні тим більш висновували мізерію, що за доказ їі взяли велич, а інші тим потужніше висновували велич, що ці висновки випливали з самої мізерії. Так і крутилися ті й ті нібито в нескінченному колі; адже певним $є$ те, що люди, мірою наявного у них світла знань знаходять у людині як такій і велич, і мізерію. Словом, людина знає, що вона мізерна. Отже, вона мізерна скоро такою $\epsilon$, але ж і велика, скоро знає про це» $[7,44]$.

Поступово заглиблюючись у роздуми Паскаля, ми бачимо не лише самотню людину, сповнену неспокою, нудьги та непевності. Набагато істотнішими та ще малодослідженими стають для нас його глибокі та надзвичайні сучасні характеристики суспільного буття людини. Ось деякі з них, на які нам, безперечно, варто зважати: «могутність королів засновано як на раціо, так і на божевіллі народу, більше, звісно, на божевіллі. Тож найбільша та найповажніша у світі річ має засадою слабкість. І ця засада напрочуд надійна, бо немає нічого певнішого за те, що народ урешті-решт виявиться слабким» [7, 17]. Зауважимо принагідно, що Паскаль був також критично налаштований щодо можливості укладання справедливої угоди між владою та суспільством, адже, на жаль, справедливим вважається переважно те, що слугує егоїстичним інтересам панівної верстви суспільства. А злиденність існування окремої людини 
зумовлена нерозумним та несправедливим суспільним ладом.

Що ж найбільше дивує французького мислителя, який знову і знову постає перед нами мудрим та розважливим, коли аналізує буття людини в спільноті інших людей? По-перше, йдеться про те, «що ніхто не дивується своїй слабкості. Все відбувається поважно: кожен тримається своєї колії не тому, що триматися ії дійсно добpe, а так, ніби кожен знає напевно, в чому полягає раціо і справедливість» $[7,18]$. По-друге, мислителя вражає властиве не лише молоді, але й зрілим людям марнославство, прагнення приховати нудьгу в розвагах та мріях про майбутнє: «позбавте їх розваг і побачите, що вони сохнутимуть 3 нудьги. Тоді вони відчуватимуть свою ніщоту, не знаючи іiі: бо дуже нещасний той, кого охоплює нестерпний смуток, скоро тільки йому доведеться розглядати своє становище і від того не відволікатись» [7, 18-19]. По-третє, головною та мало поміченою засадою нещасливого людського небажання та невміння адекватно осягати власне становище є (так актуальна для нас сьогодні) байдужість до теперішнього. Ось як звучать майже пророчі слова Паскаля: «Ми ніколи не тримаємося за теперішнє. Ми пригадуємо минуле, випереджаємо прийдешнє, що ніби надто повільно приходить, наче бажаючи прискорити його біг, або пригадуємо минуле, аби його затримати як найшвидше, ми, такі необачні, що блукаємо не в наших часах, зовсім не думаючи про той єдиний час, що нам належить. Отож, ми ніколи не живемо, а тільки сподіваємося жити i, постійно готуючись бути щасливими, $з$ неминучості ніколи щасливими не стаємо» $[7,24-$ 25]. Головне, чого ми повинні прагнути в своєму теперішньому, реальному суспільному бутті, - поєднати справедливість та силу та уникнути безсилої чи тиранічної влади, а також найбільшої біди - громадянських воєн. Останні можуть стати неминучими, «якщо кожен захоче нагороди за свої найкращі риси, адже всі скажуть, що мають такі риси» $[7,17]$. Ми мусимо не сподіватися на краще життя в майбутньому, а жити сьогодні. I знову ми бачимо цілком розважливі заклики Паскаля розумно, самостійно (як тут не пригадати роздуми І.Канта Просвітництво як вихід людини зі стану свого неповноліття) оцінювати наші думки та вчинки, вважати саме гідне сучасне буття нашою метою.

Незважаючи на свої досить песимістичні тлумачення людини, Паскаль «не може збагнути людину без думки» [7, 42], яка є осердям iiі гідності та величі: «Не в просторі я повинен шукати свою гідність, 
а в упорядкуванні власного мислення» [7, 42]. I далі ми знаходимо в тексті знамените своєю глибиною та образністю визначення людини: «Людина $є$ тільки тростинка, найслабша у природі, але це тростинка, що мислить. Щоб іï розчавити, не треба озброюватися цілому всесвітові: одного випару, однієї краплі води досить, щоб іiі вбити. Але якби Всесвіт навіть їі розчавив, людина була б усе ж чимось значно шляхетнішим, ніж те, що ііі вбиває, бо вона знає, що вмирає, і знає про ту перевагу, яку Всесвіт має над нею. А Всесвіт про це не знає нічого» $[7,80]$.

Він знову й знову говорить про притаманність людині як величі, так і мізерності. Та головною в цій суперечливій ситуації $є$ здатність людини пізнавати істину, якою б гіркою вона не була, i бути щасливою. Людина не лише може, але й мусить знати і про свою велич, і про свою жалюгідність, бо відсутність в неї такої самосвідомості є дуже небезпечною. На цій же сторінці Паскаль підсумовує: «Велич людини велика тим, що людина знає себе мізерною; дерево не знає себе мізерним. Отже, знати себе мізерним - це бути мізерним, але хто знає, що ми мізерні, той - великий» $[7,80]$. Незважаючи на значущість мислення в розумінні сутності людини, Паскаль наголошує також і на ролі серця в пізнанні істини: «...ми пізнаємо істину не лише через раціо, але й через серце. У цей спосіб ми пізнаємо перші принципи і даремно раціональне міркування, не беручи в цьому участі, силкується їх подолати» $[7,41]$. 3рештою, ми віднаходимо у Паскаля зворушливий образ людини, яка $\epsilon$ вразливою та слабкою, але й водночас стає величною через свою сердечність та розважливість. До того ж філософ не випадково демонструє читачам ницість та велич людини. Він ставить перед нею складне завдання, що потребує внутрішньої мужності, достатньо самостійної самосвідомості та здатності боротися зі своїми сумними недоліками: «Хай людина тепер сама визначить [s'estime] собі ціну. Хай вона любить себе, бо в ній є природа, здатна до добра; але хай через це вона не любить ницості, яка в ній є. Хай зневажає себе, бо ця здатність пуста; проте хай через це не зневажає і цієї природної схильності. Хай ненавидить себе, хай любить себе: в ній $\epsilon$ здатність пізнати істину і бути щасливою, проте немає ані постійної, ані задовільної істини» [7, 43]. Вже саме намагання, прагнення думати стає, за Паскалем, витоком, засадою самостійності людини та їі гідності.

У «Думках» філософ змальовує також ті риси характеру людини, 
які заважають ії гідності. Він постійно наголошує на тому, що людина не задовольняється реальним життям та наполегливо прагне до життя уявного. А також мріє про славу, якою б небезпечною вона не була. Небезпечно вкорінене в людині марнославство пустило коріння і в серце людини. Самозакоханість, за Паскалем, може завадити людині позбавитись багатьох недоліків: вона «хоче бути величною, а бачить себе малою; хоче бути щасливою, а розуміє, що нещасна; бажає бути довершеною, а знаходить в собі безліч недоліків» $[6,83]$. До того ж прагнення невиправданої поваги та любові примушує людину смертельно ненавидіти істину та приховувати свої недоліки. Крім того, самоствердженню ії заважає постійне небажання зрозуміти, проаналізувати свої хиби та позбавитись від них. Тоді й інші люди будуть ставитись до нас так, «як ми того хочемо: ми ненавидимо правду, і її ховають від нас; бажаємо словесного меду і отримуємо його; ми любимо, щоб нас ошукували, і нас ошукують» $[6,83]$. Словом, людина не бажає ні слухати, ні говорити правди і для свого ілюзорного щастя більше за все на світі прагне оманливої неправди та розваг. Неспроможні уникнути смерті та невігластва, люди намагаються забути про них, притлумити їх надмірними розвагами та речами. В окремому розділі під назвою «Розваги» Паскаль з сумом висловлює актуальну, на жаль, і на сьогодні тезу про те, що доволі часто «єдине благо людей полягає в тім, щоб їх відволікали від думок про їхнє становище чи якесь заняття, яке б відхиляло думки від цього питання, чи якась приємна і нова пристрасть, що їх займає без останку, чи гра, лови, якась захоплива вистава чи, врешті, так звана розвага» [7, 51]. Йдеться про небезпечне та позбавлене сенсу шукання марноти, яка відволікає людину від розуміння своєї природи, від «думки про себе».

На кризовий світоглядно-ціннісний вимір надмірного пошуку та споживання речей та задоволень звертає увагу в своїй грунтовній розвідці і український дослідник Р. Самчук. Він наголошує, що домінування в «життєвому світі» людини матеріальних цінностей і прагнення до «вічного теперішнього» «спричиняє трансформацію ціннісної парадигми та відображає спрямування ціннісних орієнтацій. Адже таке суспільство та його ідеологія грунтуються на міфах, симулякрах, які часто-густо нав'язані рекламою і формують споживацький світогляд, культуру, стиль життя та життєву філософію. Варто підкреслити, що під впливом споживацького суспільства культура набирає відверто гедоністичних рис, а це, своєю чергою, 
формує інертний, а подекуди й паразитичний спосіб існування» [8, 58]. Творчість Паскаля переконує, що справжня природа людини полягає в невпинному русі вперед, адже саме суще перебуває в стані вічного відновлення. Для втілення, здійснення своєї суверенності, згідно з основним спрямуванням філософської антропології Блеза Паскаля, людина також має займатися улюбленою справою. «Найстрашніше для людини - це повний спокій. Вона відчуває тоді свою немічність, свою недосконалість, свою залежність, пустоту. Відразу ж з глибини душі піднімаються нудьга, морок, горе, відчай» $[6,109]$.

Філософія Блеза Паскаля, як свідчать його твори і стверджують його дослідники та послідовники, насправді випередила свій час, демонструючи сьогодні не лише силу і слабкість людини, але й внутрішню суперечливість «модерного філософування», яке так і не змогло вповні зарадити розмаїтій у своїх проявах духовній кризі. Підсумовуючи аналіз основних понять філософської антропології Паскаля, варто погодитися 3 тим, що саме їй властиве прагнення до створення принципово нового розуміння людини та світу. Адже його уявлення про людину, її місце та покликання було вкорінене в намаганні довести непересічну значущість чіткого, послідовного мислення, що має, на нашу думку, не лише когнітивний, але й соціально-філософський, філософсько-антропологічний та етичний сенс. Важливим лейтмотивом роздумів Паскаля $є$ теза про те, що мислення є не лише осердям людської гідності - воно може зробити нас нещасними або ж щасливими, бо дає можливість ясно зрозуміти наше становище у світі. До того ж його інтелектуальний спадок $\epsilon$ загальноєвропейським. Адже до нього «ніхто в європейській традиції так натхненно та жорстко не описував нездоланну суперечливість людського буття, його щомиттєву вразливість у просторовому і часовому безмежжі Всесвіту» $[9,8]$. Словом, без Паскалевого розуміння простору як потенційної нескінченності ми, напевно, не могли б зрозуміти й актуальну нескінченність Декарта, яка й до сьогодні дає людині надію та захоплює іiі, про що свого часу писав М.Мамардашвілі в своїх «Картезіанських роздумах» [10]. I сьогодні нам не варто (і завдяки Блезу Паскалю також) забувати, що лише вільна та відповідальна думка може стати тим моральним орієнтиром та гідним людини простором свободи, який вбереже нас від численних маніпуляцій, непотрібних спокус і міфологізацій та визначить перспективу гідного людини соціального буття. 


\section{ЛІТЕРАТУРА}

1. Хома О. «Думки» і герменевтика: філософське значення Нової апологетики Паскаля // Паскаль Б. Думки. - К., 2009. - С. 395-409.

2. Аверинцев С. София-Логос. Словарь. - К., 2006. - 640 с.

3. Tiedemann $P$. Menschenwbrde als Rechtsbegriff. Eine philosophische Klдrung.. - Berlin, 2012. $-721 \mathrm{~S}$.

4. Wallau $P h$. Die Menschenwbrde in der Grundrechtsordnung der Europдischen Union. - Bonn, 2010. - 338 S.

5. Стрельиова Г.Я. Паскаль и европейская культура. - М., 1994. - 495 с.

6. Паскаль Б. Мысли. - М., 1994. - 528 с.

7. Паскаль Б. Думки. - К., 2009. - 704 с.

8. Самчук $P$. Криза цінностей через призму споживацького суспільства // Мультиверсум. Філософський альманах. - К., 2014. - Випуск 1(129). C.56- 68 .

9. Малахов В. Вступне слово // Паскаль Б. Думки. - К., 2009. - С. 8-10.

10. Мамардашвили М. Картезианские размышления. - М., 1993. - 165 с.

Петренко М.О. Ідея суверенності та гідності людини у філософській антропології Блеза Паскаля.

Предмет дослідження статті - основні поняття філософської та політичної антропології Б. Паскаля, який, разом зі своїм знаменитими сучасниками Ф. Беконом та Р. Декартом, стояв у витоків формування сучасної філософії людини. Запропонований нами аналіз роздумів Паскаля про суверенність та гідність людини надає можливість глибше зрозуміти сутність історичної трансформації проблеми людської гідності та розмаїття іiі історико-філософських дискурсів. 3'ясовано, що окреслені в статті глибинно-трагічні мотиви в осмисленні Паскалем людського буття, «величі» та «нікчемності» людини привертали увагу не лише С.К'єркегора, А.Камю, Ж.-П.Сартра, але й новітніх представників філософсько-антропологічної думки. Всебічно розгорнуто тезу про те, що саме людина була осердям його роздумів Паскаля. А їі самосвідомість, самопізнання, якщо не допоможе людині віднайти істину, то напевне допоможе прожити гідне життя. Це також - чи не єдиний шлях до подолання людиною своїх істотних недоліків та до вдосконалення власної недосконалої природи. Філософській антропології Паскаля притаманне як розчарування в людині, так і щире захоплення нею і її розумом.

Ключові слова: людина, гідність, філософська антропологія, буття, природа людини, мислення, самосвідомість. 
Петренко М. Идея независимости и достоинства человека в философской антропологии Блеза Паскаля.

Предмет исследования статьи - основные понятия философской и политической антропологии Б.Паскаля, который, вместе со своими знаменитыми современниками Ф.Бэконом и Р.Декартом, несомненно, стоял у истоков формирования современной философии человека. Предложенный нами анализ размышлений Паскаля о независимости и достоинстве человека дает возможность глубже понять сущность исторического генезиса проблемы человеческого достоинства и многообразие ее историко-философских дискурсов. Установлено, что указанные в статье трагические мотивы в осмыслении Паскалем человеческого бытия, «величия» и «ничтожности» человека привлекали внимание не только С.Кьеркегора, А.Камю, Ж.-П.Сартра, но и новейших представителей философско-антропологической мысли. Всесторонне развернут тезис о том, что именно человек был центром размышлений Паскаля. А его самосознание, самопознание поможет человеку найти истину и прожить достойную жизнь. Это также почти единственный путь к преодолению человеком своих существенных недостатков и к совершенствованию собственной несовершенной природы. Философской антропологии Паскаля присуще как разочарование в человеке, так и искреннее восхищение им, его умом, верой в творческие возможности.

Ключевые слова: человек, достоинство, философская антропология, бытие, природа человека, мышление, самосознание.

Petrenko M. The idea of sovereignty and dignity in Blaise Pascal's philosophical anthropology.

The topic of the study is the main notions of Paskal's philosophic and political anthropology, who was standing at the cradle of modern human philosophy as well as his famous contemporaries F. Bekon and R. Decarth. Paskal's thoughts about the independence and dignity of a person helps to understand more deeply the issue of person's dignity in the variety of different historicphilosophical discourses. It was proved, that the tragic motives in Pascal's understanding of human existence, «greatness» and «nothingness» of man, outlined in article, attracted the attention not only of S.K'yerkehorge, A.Kamu, Jean-P.Sartr, but also representatives of new philosophic-antropologic thought. The thesis about a human being the central core with consciousness and selfstudying as a way to find the Truth and live a worthy life, has been thoroughly outlined. It is also not the only way of a human to overcome their substantial drawbacks and improving their imperfect nature. Philosophic anthropology of Pascal has both disappointment and sincere admiration of a human, their mind and a belief in their creative possibilities.

Key words: human, dignity, philosophic anthropology, being, human nature, mind, consciousness. 